\title{
UJI DAYA HAMBAT PERTUMBUHAN BAKTERI Escherichia coli MENGGUNAKAN EKSTRAK RIMPANG KUNYIT Curcuma domestica val
}

\section{Fitri Rahmi Fadhilah, Arie J Pitono, Gita Fitriah}

\begin{abstract}
ABSTRAK
Latar Belakang:Rimpang kunyit merupakan bagian dari tanaman dengan berbagai khasiat salah satunya dapat menurunkan jumlah bakteri Escherichia coli. Kandungan senyawa bermanfaat dalam rimpang kunyit salah satunya yang bersifat antibakteri yang meliputi fenol, saponin dan flavonoid.
\end{abstract}

Tujuan Penelitian:Untuk mengetahui zona hambat yang terbentuk pada bakteri Escherichia coli dengan menggunakan ekstrak rimpang kunyit (Curcuma domestica val).

Metode Penelitian:Penelitian eksperimentaldenganmetode difusi cakram (Kirby Bauer) dengan 3 perlakuan.

Hasil penelitian: Penelitian yang telah dilakukan menunjukan bahwa konsentrasi daya hambat pertumbuhan bakteri Escherichia coli pada konsentrasi 20\% (8,6 mm), 33,3\% (16 $\mathrm{mm})$ dan $42,8 \%(25,3 \mathrm{~mm})$.

Simpulan: Terdapat zona hambat bakteri Escherichia coli dengan menggunakan ekstrak rimpang kunyit, Sehingga ekstrak rimpang kunyit dapat dijadikan antibakteri baru dengan memanfaatkan bahan alam atau herbal yang dapat mengurangi risiko resistensi bakteri terhadap antibakteri.

Kata Kunci: Rimpang Kunyit, Escherichia coli, Uji Daya Hambat

\section{PENDAHULUAN}

Begitu banyak mikroorganisme dalam hidup kita yang tanpa kita sadari selalu ada dilingkungan kita. Salah satu mikroorganisme yang selalu ada disekitar kita adalah bakteri (kuswiyanto, 2015). Bakteri dapat hidup dimana dan akan menguntungkan bagi kehidupan manusia namun bisa saja bakteri tersebut menjadi merugikan bagi kehidupan manusia karena menghasilkan suatu infeksi. 
Saat ini infeksi yang disebabkan oleh bakteri semakin sering dilaporkan di Indonesia dan sebagai negara beriklim tropis ditemukan prevalensi dari penyakit tropis dan infeksi yang tinggi (Misnadiarly \& Djajaningrat, 2014). Salah satu bakteri penyebab infeksi adalah Escherichia coli.

Escherichia coli merupakan flora normal dalam saluran pencernaan, namun dapat menjadi patogen apabila jumlahnya meningkat atau berada diluar saluran pencernaan. Bila Escherichia coliterdapat dalam air ataupun makanan yang mengandung air, terindikasi bahwa air tesebut terkontaminasi feces(Lubis, 2015). Gejala umum dari infeksi Escherichia coli adalah diare yang mendadak, parah, berair atau berdarah; kram atau nyeri pada perut; mual dan muntah; kehilangan nafsu makan; kelelahan dan demam. Sedangkan gejala serius dari infeksi Escherichia colimeliputi urin berdarah, berkurangnya jumlah urin, kulit pucat, memar dan dehidrasi (Samiadi, 2016).

Perkembangan antimikrobial dan terapi suportif pada penyakit infeksi dari tahun ke tahun bekembang, tetapi disisi lain pemakaian yang tidak tepat akan merugikan bahkan dapat menimbulkan kekebalan kuman atau resistensi (Misnadiarly \& Djajaningrat, 2014). Resistensi terhadap antibakeri dapat terjadi melalui tiga mekanisme, yaitu afinitas yang berubah pada saat pengikatan pada sasaran, permeabilitas yang menurun terhadap antibakteri yang bersangkutan atau keberadaan enzim inaktivasi (Muliawan, 2008).

Resistensi terhadap antibakteri menjadi masalah, sehingga diperlukan usaha untuk mengembangkan obat-obatan jenis baru yang dapat mencegah terjadinya resistensi. Penelitian zat yang berkhasiat sebagai antibakteri baru yang berpotensi menghambat atau membunuh bakteri yang resisten terhadap antibakteri perlu dilakukan. Salah satu caranya dengan mengembangkan pengobatan tradisional yang memanfaatkan tanaman yang dapat membunuh bakteri untuk menghindari terjadinya resistensi (Kurniawan \& Aryana, 2015).

Kunyit (Curcuma domestica val) merupakan salah satu tanaman yang mudah ditemui diberbagai wilayah Indonesia sehingga sudah sangat dikenal oleh masyarakat.Sementara itu, kemampuan kunyit dalam menghambat pertumbuhan bakteri penyebab keracunan makanan atau infeksi saluran pencernaan (Escherichia colidan Staphylococcus aureus), adanya hambatan terhadap bakteri ini akibat adanya kandungan senyawa fenolik yang bersifat antimikroba (Utami \& Puspaningtyas, 2013). 
Kurkuminoid dalam rimpang kunyit (Curcum domestica val) merupakan senyawa fenolik dan mekanisme kerja kurkumin sebagai antibakteri mirip dengan persenyawaan fenol lainnya yaitu menghambat metabolisme bakteri dengan cara merusak membran sitoplasma serta mendenaturasi protein sel yang menyebabkan kebocoran nutrient dari sel sehingga sel bakteri mati atau terhambat pertumbuhannya (Ramadhani dkk., 2017).

Berdasarkan dari hasil penelitian yang telah dilakukan oleh Rini, Rohmah \& Widyaningrum (2018) didapatkan hasil bahwa ekstrak kering rimpang kunyit (Curcuma domestica val) memiliki aktivitas antibakteri karena kandungan didalamnya yaitu salah satunya kurkumin yang dapat menghambat metabolisme bakteri dengan cara merusak membran sitoplasma serta mendenaturasi protein sel terhadap bakteri Escherichia colidan Bacillus subtilis. Penelitian ini menggunakan metode eksperimental laboratoris dengan 8 perlakuanyaitu konsentrasi $0 \%, 15 \%, 30 \%, 45 \%, 60 \%, 75 \%, 90 \%, 100 \%$ dengan jumlah pengulangan 3 kali dengan hasil memperlihatkan adanya variasi zona hambat yang terbentuk dari ekstrak kering kunyit terhadap masing-masing perlakuan. Pada penelitian ini,ekstrak kering kunyit pada konsentrasi $15 \%$ sudah memiliki daya antibakteri terhadap Escherichia coli $(0,63 \mathrm{~mm})$ dan Bacillus subtilis $(0,7 \mathrm{~mm})$. Metode yang digunakan untuk menguji antibakteri menggunakan metode difusi yaitu menggunakan kertas cakram pada media Muller Hinton Agar (MHA).

Dari uraian diatas penulis ingin melakukan penelitian mengenai uji daya hambat pertumbuhan bakteriEscherichia coli menggunakanekstrak rimpang kunyit (Curcuma domestica val).

\section{METODE}

Penelitian ini merupakan penelitian eksperimental yang bertujuan untuk mengetahui konsentrasi ekstrak rimpang kunyit (Curcuma domestica val) dalam menghambat pertumbuhan bakteri Escherichia colidengan menggunakan cakram difusi Kirby Bauer. Variabel pada penelitian ini adalah ekstrak rimpang kunyit (Curcuma domestica val) pada pertumbuhan bakteri Escherichia coli dengan 3 perlakuan yaitu konsentrasi 20\%, 33,3\% dan 42,8\%. Penelitian dilakukan dilaboratorium Bakteriologi DIII Analis Kesehatan Sekolah Tinggi Ilmu kesehatan Rajawali Bandung pada bulan Februari - Juli 2019.

Bahan yang digunakan pada penelitian antara lain rimpang kunyit (Curcuma domestica val) yang didapatkan dari pasar Ciroyom Bandung yang kemudian dideterminasi 
untuk mengurangi kesalahan dalam melakukan pengumpulan bahan yang akan digunakan dalam pembuatan ekstrak pada penelitian, biakan murni bakteri Escherichia coli, medium Mac Conkey, medium Muller Hinton Agar sebagai media uji daya hambat baketri dan standar Mc Farland 0,5\% (1\% asam sulfat 99,5 mL dan 1,175\% barium klorida dihidrat 0,5 mL).

Rimpang kunyit dikumpulkan dan dicuci bersih kemudian dipotong tipis dengan ketebalan berkisar $3 \mathrm{~mm}$ dan dikeringkan hingga kadar air yang tersisa didalamnya 10-15\%, digiling dan diayak (ukuran kehalusan antara 0,1-0,3 cm) kemudian dimasukan 1 bagian simplisia direndam dengan 7,5 bagian etanol 96\% dan dibiarkan selama 5 hari (sesekali diaduk setiap hari) hal ini dilakukan ditempat yang terlindung dari cahaya matahari. Hasil ekstraksi dimasukan kedalam evaporator dengan waktu penguapan selama 2 jam dengan suhu $30-40^{\circ}$.

Selanjutnya dilakukan uji fitokimia untuk mengetahui kandungan senyawa aktif yang terkandung dalam rimpang kunyit tersebut. Kemudian lakukan pengenceran untuk membuat konsentrasi $20 \%$ dengan menambahkan $1 \mathrm{~mL}$ aquades steril kedalam 0,25 gekstrak rimpang kunyit, 33,3\% dengan menambahkan $1 \mathrm{~mL}$ aquades steril kedalam 0,50 gekstrak rimpang kunyit dan $42,8 \%$ dengan menambahkan $1 \mathrm{~mL}$ aquades steril kedalam 0,75 gekstrak rimpang kunyit.

Biakan murni Escherichia coli diinokulasikan pada media Mac Conkey selama 24 jam pada suhu $37^{\circ} \mathrm{C}$. Setelah itu bakteri diambil 1 ose dan dimasukan kedalam $1 \mathrm{~mL} \mathrm{NaCl}$ fisiologis sampai didapat kekeruhan setara dengan standar Mc Farland 0,5\%, kemudian ambil dengan swab steril dan diinokulasikan pada medium Muller Hinton Agar dan tempelkan kertas cakram yang ditetesi $20 \mu \mathrm{L}$ ekstrak rimpang kunyit dengan masing-masing konstrasi yang telah dibuat dan inkubasi selama 16-18 jam dengan suhu $35^{\circ} \mathrm{C}$. pengamatan dan pengukuran berdasarkan terbentuknya zona bening disekitar kertas cakram menggunakan mistar, kemudian dihitung dengan menggunakan rumus :
$\underline{(\mathrm{DV}-\mathrm{DC})+(\mathrm{DH}-\mathrm{DC})}$
Ket: - DV : Diameter Vertikal
- DH : Diameter Horizontal
- DC : Diameter Cakram 


\section{HASIL}

Hasil Ekstrak Rimpang Kunyit (Curcuma domestica val) dengan menggunakan pelarut etanol $96 \%$ dengan menggunakan metode maserasi sebagai berikut:

Tabel 1. Hasil Ekstrak Rimpang Kunyit

\begin{tabular}{|c|c|c|c|}
\hline $\begin{array}{c}\text { Berat Kering } \\
\text { Rimpang Kunyit }\end{array}$ & Pelarut & Volume Pelarut & Hasil Ekstrak \\
\hline $1 \mathrm{~kg}$ & Etanol 96\% & 2,4 Liter & $\begin{array}{c}49,5 \text { gram cairan } \\
\text { kental }\end{array}$ \\
\hline
\end{tabular}

Hasil UjiFitokimia Ekstrak Rimpang Kunyit (Curcuma domestica val) dengan hasil sebagai berikut:

Tabel 2. Data Hasil UjiFitokimia Ekstrak Rimpang Kunyit

\begin{tabular}{|c|c|}
\hline Senyawa & Hasil \\
\hline Alkaloid & Negatif \\
\hline Tanin & Negatif \\
\hline Fenol & Positif \\
\hline Saponin & Positif \\
\hline Flavonoid & Positif \\
\hline
\end{tabular}

Hasil Uji Pendahuluandidapat nilai uji daya hambat pada setiap konsentrasi ekstrak rimpang kunyit (Curcuma domestica val)dapat menghambat pertumbuhan bakteri Escherichia coli.

Tabel 3. Data Hasil Uji Pendahuluan

\begin{tabular}{|c|c|c|c|}
\hline \multirow{2}{*}{ Pengulangan } & \multicolumn{3}{|c|}{ Diameter Zona Hambat (mm) } \\
\cline { 2 - 4 } & Kontrol & Kontrol & $\begin{array}{c}\text { Konsentrasi ekstrak } \\
\text { rimpang kunyit }\end{array}$ \\
\hline
\end{tabular}




\begin{tabular}{|c|c|c|c|c|c|}
\hline & $(-)$ & $(+)$ & $4,7 \%$ & $9 \%$ & $13 \%$ \\
\hline 1 & $0 \mathrm{~mm}$ & $36 \mathrm{~mm}$ & $0 \mathrm{~mm}$ & $4 \mathrm{~mm}$ & $10 \mathrm{~mm}$ \\
\hline
\end{tabular}

Uji pendahuluan dilakukan untuk menentukan konsentrasi yang akan diujikan. Pengujian ini dilakukan terlebih dahulu untuk menghindari adanya penelitian yang berulangulang. Pengujian ini dilakukan dengan metode difusi yang bertujuan untuk mengetahui adanya hambatan berupa zona bening yang terlihat pada medium pertumbuhan dan melihat ada tidaknya pertumbuhan Escherichia coli disekitar kertas cakram.

Hasil Uji Daya Hambatdidapat nilai uji daya hambat pada setiap konsentrasi ekstrak rimpang kunyit(Curcuma domestica val)dapat menghambat pertumbuhan bakteri Escherichia coli

Tabel 4. Data Hasil Uji Daya Hambat

\begin{tabular}{|c|c|c|c|c|c|}
\hline \multirow{2}{*}{ Engulangan } & \multicolumn{4}{|c|}{ Diameter Zona Hambat (mm) } \\
\cline { 2 - 6 } & Kontrol & Kontrol & \multicolumn{3}{|c|}{ Konsentrasi ekstrak rimpang } \\
& & & \multicolumn{3}{c|}{ kunyit } \\
\cline { 2 - 6 } & $(-)$ & $(+)$ & $20 \%$ & $33,3 \%$ & $42,8 \%$ \\
\hline 1 & $0 \mathrm{~mm}$ & $32 \mathrm{~mm}$ & $10 \mathrm{~mm}$ & $14 \mathrm{~mm}$ & $26 \mathrm{~mm}$ \\
\hline 2 & $0 \mathrm{~mm}$ & $32 \mathrm{~mm}$ & $12 \mathrm{~mm}$ & $16 \mathrm{~mm}$ & $28 \mathrm{~mm}$ \\
\hline Rata-rata & $0 \mathrm{~mm}$ & $32 \mathrm{~mm}$ & $4 \mathrm{~mm}$ & $12 \mathrm{~mm}$ & $22 \mathrm{~mm}$ \\
\hline
\end{tabular}

Pada tabel hasil uji daya hambat diatas dapat dilihat kontrol positif (32 mm), kontrol negatif $(0 \mathrm{~mm})$ dan pada pengulangan pertama didapatkan hasil 20\% (10 mm), 33,3\% (14 $\mathrm{mm}$ ) dan 42,8\% (26 mm). Pengulangan kedua didapatkan hasil 20\% (12 mm), 33,3\% (16 $\mathrm{mm}$ ) dan 42,8\% (28 mm). Pengulangan ketiga didapatkan hasil 20\% (4 mm), 33,3\% (12 mm) dan 42,8\% (22 mm) apabila dirata-ratakan maka didapatkan hasil 20\% (8,6 mm), 33,3\% (16 $\mathrm{mm})$ dan 42,8\% (25,3 mm). Jika diamati terdapat perubahan diameter zona bening pada pengulangan terlihat sangat berbeda dari pengulangan pertama dan kedua. 


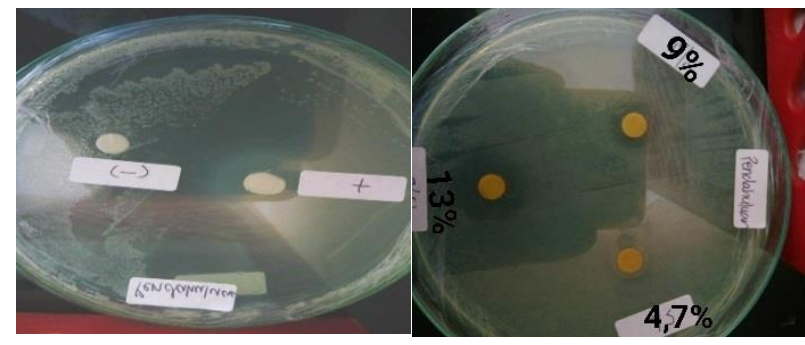

Gambar 1. Daya Hambat Pada Uji Pendahuluan

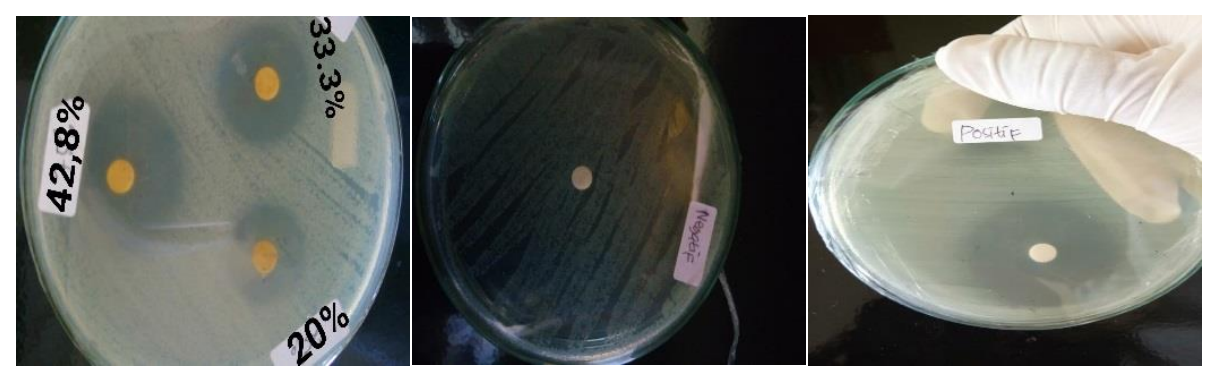

Gambar 2. Zona Hambat Ekstrak Rimpang Kunyit Terhadap Escherichia coli

\section{PEMBAHASAN}

Determinasi tanaman berfungsi untuk mengurangi kesalahan dalam melakukan pengumpulan bahan yang akan digunakan dalam pembuatan ekstrak pada penelitian. Determinasi tanaman dilakukan dengan mencocokkan ciri-ciri yang akan diidentifikasi dengan deskripsi serta gambar-gambar yang ada dalam pustaka (Aryulina, 2006). Ekstraksi dengan menggunakan metode maserasi. Metode ini dipilih karena prosesnya sederhana dan senyawa-senyawa yang termolabil tidak akan rusak (Sutrisna, 2016). Pelarut yang digunakan untuk ekstraksi metode maserasi adalah etanol 96\%. Pelarut etanol 96\% dipilih karena dapat membuat zat aktif tersaring lebih banyak serta dapat memperbaiki stabilitas zat yang terlarut dan tidak menyebabkan pembengkakkan pada membran sel bakteri. Sehingga pada saat pengujian ekstrak rimpang kunyit tidak akan berpengaruh terhadap hasil yang didapatkan (Febriani, 2016).

Selanjutnya dilakukan uji daya hambat bakteri Escherichia coli dengan menggunakan ekstrak rimpang kunyit Curcuma domestica val dengan metode difusi cakram (Kirby Bauer). Metode ini dipilih karena mudah dilakukan, tidak memerlukan peralatan khusus, cukup murah dan cocok untuk sampel rimpang kunyit yang mempunyai warna keruh. 
Medium yang digunakan pada metode difusi Kirby Bauer merupakan medium Muller Hinton Agar (MHA) karena medium ini bukan merupakan medium selektif ataupun differensial sehingga semua jenis bakteri dapat tumbuh, mempermudah difusi, zona bening akan jelas terlihat dan tidak mengandung bahan yang akan menghambat cara kerja antibakteri.

Dalam penelitian ini, dilakukan uji pendahuluan untuk menentukan konsentrasi yang akan diujikan terlebih dahulu dan untuk menghindari adanya penelitian yang berulang-ulang. pada konsentrasi 5\% (0 mm), 10\% (4 mm), 15\% (10 mm) disertakan kontrol positif $(36 \mathrm{~mm})$ dengan menggunakan antibiotik kloramfenikol karena mekanisme kerjanya sama dengan senyawa kurkumin pada kunyit yaitu dengan cara menghambat sintesis protein yang dibutuhkan untuk pembentukan sel-sel bakteri dengan menghambat fungsi RNA pada bakteri dan kontrol negatif $(0 \mathrm{~mm})$ dengan menggunakan aquades steril, aquades steril dipilih karena senyawa kurkumin dalam rimpang kunyit adalah golongan polifenol yang bersifat polar sehingga dapat larut dalam aquadest yang bersifat polar juga serta aquadest tidak akan mempengaruhi hasil karena tidak bersifat bakterisida hal ini dapat dilihat dari zona bening yang tidak terbentuk.

Dari uji pendahuluan dapat dilihat pada konsentrasi 4,7\% (0 mm) tidak terdapat zona bening , 9\% (4 mm), 13\% (10 mm), sedangkan kontrol positif (36 mm) jika dilihat pada tabel CLSI (Clinical and Laboratory Standart Institute) $36 \mathrm{~mm}$ untuk kloramfenikol merupakan nilai sensitif pada uji kepekaan sehingga perlu dinaikkan kosentrasi uji sebenarnya untuk melihat daya hambat yang mendekati atau melebihi diameter kontrol positif dari ekstrak rimpang kunyit, yaitu konsentrasi 20\%, 33,3\% dan 42,8\% dengan pengulangan tiga kali yang bertujuan untuk mengetahui presisi dan akurasi dari hasil yang dianalisa.

Berdasarkan uji pendahuluan pada konsentrasi $9 \%$ sudah menghambat dengan diameter zona hambat $4 \mathrm{~mm}$ diduga daya hambat ini disebabkan oleh komponen zat aktif yang terkandung di dalamnya. Pada pengujian fitokimia di dapatkan hasil bahwa ekstrak rimpang kunyit mempunyai kemampuan sebagai antibakteri. Kandungan zat yang dimiliki ekstrak rimpang kunyit dapat menghambat aktifitas bakteriEscherichia coli diantaranya fenol, saponin dan flavonoid.

Fenol dalam membunuh mikroorganisme yaitu dengan mendenaturasi protein sel. Ikatan hidrogen yang terbentuk antara fenol dan protein mengakibatkan struktur protein menjadi rusak. Saponin sebagai antibakteri yaitu dapat menyebabkan kebocoran protein dan enzim dari dalam sel. Saponin dapat menjadi antibakteri karena zat aktif permukaannya mirip 
detergen, akibatnya saponin akan menurunkan tegangan permukaan dinding sel bakteri dan merusak permebialitas membran. Flavonoid menghambat fungsi membran sel adalah membentuk senyawa kompleks dengan protein ekstraseluler dan terlarut sehingga dapat merusak membran sel bakteri dan diikuti dengan keluarnya senyawa intraseluler (Rijayanti, 2014).

Pada uji sebenarnya kontrol positif $(32 \mathrm{~mm})$, kontrol negatif $(0 \mathrm{~mm})$ dan pada pengulangan pertama didapatkan hasil 20\% (10 mm), 33,3\% (14 mm) dan 42,8\% (26 mm). Pengulangan kedua didapatkan hasil 20\% (12 mm), 33,3\% (16 mm) dan 42,8\% (28 mm). Pengulangan ketiga didapatkan hasil 20\% (4 mm), 33,3\% (12 mm) dan 42,8\% (22 mm) apabila dirata-ratakan maka didapatkan hasil 20\% (8,6 mm), 33,3\% (16 mm) dan 42,8\% (25,3 $\mathrm{mm})$. Jika diamati terdapat perubahan diameter zona bening pada kontrol positif saat uji pendahuluan dengan uji sebenarnya, hal ini terjadi juga pada konsentrasi $20 \%$ pengulangan pertama $10 \mathrm{~mm}$, pengulangan kedua $12 \mathrm{~mm}$ dan pengulangan ketiga $4 \mathrm{~mm}$ jika dilihat pada uji pendahuluan pada konsentrasi $13 \% 10 \mathrm{~mm}$ yang artinya diameter zona bening terbentuk sama bahkan pada pengulangan ketiga uji sebenarnya diameter yang terbentuk lebih kecil 6 $\mathrm{mm}$, selain itu variasi nilai pada pengulangan ketiga terlihat sangat berbeda dari pengulangan pertama dan kedua.

Kemungkinan hal ini terjadi karena pada saat penuangan medium MHA pada setiap cawan berbeda, meskipun pada saat penuangan medium MHA dilakukan pengukuran dengan mengukur medium MHA dengan gelas ukur (4 mm setara dengan $20 \mathrm{~mL}$ ) hal inilah yang kurang diperhatikan oleh peneliti sehingga mejadi salah satu faktor kemungkinan terjadinya hal tersebut, karena ketebalan medium MHA yang baik adalah 4 mm, apabila kurang difusi obat cepat dan lebih dari itu difusi obat lambat.

Perbedaan hari penelitian pada uji pendahuluan, uji sebenarnya pengulangan pertama dan kedua, serta pengulangan ketiga yang diduga menjadi faktor nilai yang sangat berbeda perlakuan yang dilakukan bisa saja mempengaruhi seperti suspensi bakteri yang terdapat pada swab kurang diperas pada dinding tabung meskipun konsentrasi ekstrak, suspensi bakteri, waktu dan suhu inkubasi yang sama.

Suhu inkubator menjadi faktor selanjutnya karena pada saat pengulangan pertama dan pengulangan kedua inkubator tidak menyala yang kemungkinan suhu menjadi turun dan kemungkinan terjadi variasi nilai yang berbeda pada diameter zona hambat pengulangan ketiga karena apabila suhu kurang dari $35^{\circ} \mathrm{C}$ menyebabkan diameter zona hambatan lebih 
lebar sehingga resisten dapat dilaporkan sensitif. Selain itu faktor waktu pengeringan/ peresapan suspensi bakteri kedalam agar MHA yang kurang diperhatikan sehingga melebihi batas yang ditentukan dapat mempersempit diameter zona.

Adapun hal lain yang mempengaruhi diameter pengulangan ketiga menjadi lebih sempit, kurang homogennya larutan konsentrasi ekstrak rimpang kunyit sehingga senyawa antibakteri yang terkandung dalam larutan konsentrasi tidak terpipet pada kertas cakram.

\section{SIMPULAN}

Berdasarkan penelitian yang dilakukan dapat disimpulkan bahwa ekstrak rimpang kunyit Curcuma domestica val dapat menghambat pertumbuhan bakteri Escherichia coli pada konsentrasi 20\% dengan diameter 8,6 mm, pada konsentrasi 33,3\% dengan diameter $16 \mathrm{~mm}$ dan pada konsentrasi $42,8 \%$ dengan diameter $25,3 \mathrm{~mm}$. sehingga ekstrak rimpang kunyit Curcuma domestica val dapat dijadikan antibakteri baru dengan memanfaatkan bahan alam atau herbal yang dapat mengurangi risiko resistensi bakteri terhadap antibakteri.

\section{REFERENSI}

Aryulina D, Muslim C, Manaf S, Winarni EW. Wijayanti E, editor. Biologi 1: SMA dan MA untuk kelas X. Jakarta Timur: Esis; 2004.

Febriani RR. Gambaran efektivitas ekstrak kunyit kuning (Curcuma longa linn) sebagai antibakteri terhadap pertumbuhan Salmonella typhi secara invitro. Karya Tulis Ilmiah: Sekolah Tinggi Ilmu Kesehatan Rajawali Bandung; 2016.

Kurniawan B, Aryana WF. Binahong (Cassia alata L) as inhibitor of Escherichia coli growth. J MAJORITY 2015 Feb; 4(4):100-4.

Kuswiyanto. Mardella EA, editor. Bakteriologi 1: buku ajar analis kesehatan. Jakarta: EGC; 2015.

Lubis PAH. Identifikasi bakteri Escherichia coli serta Salmonella sp yang diisolasi dari soto ayam. Laporan Penelitian: UIN Syarif Hidayatullah Jakarta; 2015.

Misnadiarly, Djajaningrat H. Mikrobiologi untuk klinik dan laboratorium. Jakarta: Rineka cipta; 2014. 
Muliawan SY. Bakteri anaerob: yang erat kaitannya dengan problem klinik. Jakarta: EGC; 2007.

Ramadhani R, Erly, Asterina. Hambat ekstrak etanol rimpang kunyit (Curcuma domestica V.) terhadap pertumbuhan bakteri staphylococcus aureus secara in vitro. Jurnal Kesehatan Andalas 2017;6(3):590-5.

Samiadi LA. Infeksi bakteri E.coli. [Online]. 2016 [cited 2019 Feb 12]; Available from: URL:https://hellosehat.com/penyakit/infeksi-bakteri-e-coli/

Sutrisna E. Herbal medicine: suatu tinjauan farmakologis. Surakarta: Muhammadiyah university press; 2016.

Utami P, Puspaningtyas DE. Indah Y, editor. The miracle of herbs. Jakarta: Agro Media Pustaka; 2013. 